принципе учета влияния коммуникативного намерения на структурно-смысловую организацию текста как ведущего при анализе дискурса научного текста / C. А. Вишнякова // Материалы XXXVIII межд. филол. конф.: Русский язык как иностранный и методика его преподавания. - СПб. - 2008. - Вып. 20. - С. 141-150. 3. Вишнякова С. А. Функциональный подход к обучению понимания научноучебного теста (на материале делового общения)/ С. А. Вишнякова // Актуальные проблемы гуманитарного знания в техническом вузе (II Всероссийская научнометодическая конференция). - СПб. - 2009. - С. 120-122. 4. Гаршин А. П. Толковый словарь по химии для школьника, абитуриента, студента / А. П. Гаршин. - СПб.: Изд-во «Деан», 2004. - 336 с. 5. Пидкасистый П. И. Теоретические основы обучения студентов знаниям и методам познавательной деятельности / П. И. Пидкасистый, Б. И. Коротяев, В. И. Хозяинов // Современная высшая школа. - 1980. - № 2. - С. 138-143. 6. Сатбалдина С. Т. Рекомендации по моделированию учебной деятельности с целью развития творческого мышления на уроках химии/ С. Т. Сатбалдина // Методика формирования системы знаний при изучении химических дисциплин в педвузе: сб. науч. работ. - М., 1983. - С. 159-167. 7. Хомченко Г. П. Пособие по химии для поступающих в вузы / Г. П. Хомченко. - М. : Издательство «Новая Волна», 2000. - 464 с.

УДК 378. 147

Тетяна Чухно

\title{
КУЛЬТУРОЛОГІЧНІ АСПЕКТИ ФОРМУВАННЯ ПРОФЕСІЙНО ОРІЄНТОВАНОЇ ОСОБИСТОСТІ МАЙБУТНЬОГО ВИКЛАДАЧА
}

Чухно Т. В. Культурологічні аспекти формування професійно орієнтованої особистості майбутнього викладача.

У статті висвітлено, теоретично обгрунтовані питання підготовки майбутнього викладача через гуманітаризацію змісту професійної освіти в сучасних умовах, запропоновано шляхи формування професійно орієнтованої особистості майбутнього викладача на основі культурологічного підходу та визначено педагогічні умови імплементації цих завдань.

Ключові слова: культурологічний підхід, культура, професійна освіта, професійна підготовка, педагогічна діяльність.

Чухно Т. В. Культурологические аспекты формирования профессионально ориентированной личности будущего преподавателя.

В статье освещены теоретически обоснованные вопросы подготовки будущего преподавателя с помощью гуманитаризации содержания профессионального образования в современных условиях, предложены пути формирования профессионально ориентированной личности будущего преподавателя на основе культурологического подхода, также определены педагогические условия имплементации этих задач.

Ключевые слова: культурологический подход, культура, профессиональное образование, профессиональная подготовка, педагогическая деятельность.

Chukhno T. V. Cultural aspects of developing professionally-oriented personality of the future teacher.

The article highlights some issues concerning theoretically substantiated training the future teacher through humanizing the content of professional education in present-day conditions. The author offers the ways of developing professionally-oriented personality of 
the future teacher on the basis of cultural approach. The author also defines the pedagogical conditions of implementing these tasks.

Key words: culturological approach, culture, professional education, professional training, pedagogic activity.

Створення в Україні національної системи освіти на принципах гуманізму, духовності та патріотизму зумовлює необхідність кардинальних змін у професійній підготовці викладача, від особистості якого великою мірою залежить успішне досягнення нових освітніх цілей. 3 огляду на виклики сьогодення, які стоять перед світовою спільнотою взагалі, та українськими громадянами зокрема, особливої актуальності набуває обрана тема.

Завдання сучасної освіти вищої педагогічної школи полягає не тільки в тому, щоб підготувати гармонійно розвинутого та висококваліфікованого спеціаліста у своїй справі, а й у тому, щоб підготувати педагога-майстра, який глибоко розуміє й усвідомлює свою роль у суспільстві, уміє творчо використовувати здобуті знання на практиці, цінує колективний досвід, думку колег, культивує кращі риси української ментальності та виховує у студентів бережливе ставлення до національного багатства країни, мові, культури, традицій. Розв'язання цієї проблеми започатковується у вищому педагогічному закладі i передбачає насамперед реалізації ціннісноорієнтованого й культурологічного підходу до змісту педагогічної освіти.

Meта статmi - охарактеризувати процес формування професійно орієнтованої особистості майбутнього викладача на основі культурологічного підходу.

Нині особливо важливо приділити більше уваги підготовці викладача як вихователя задля оволодіння найскладнішою наукою- формуванням особистості людини. У межах публікації сфокусуємося на створенні системи формування професійної особистості викладача як мислителя, гуманіста, майстра своєї справи, який опанував теоретичні, практичні та наукові засади педагогічної освіти.

Інноваційні процеси в суспільстві, зміна цінностей та орієнтацій, збільшення потреби в індивідуальній активності та відповідальності вимагають від системи освіти перегляду концептуальної системи поглядів на професійну освіту у вищій школі і тому невипадково зміцнюється увага дослідників до особистості викладача, до іiї духовного і професійного формування та становлення (О. Бабічев, Н. Крилова, Я. Поторій та ін.).

Водночас нині у навчальних планах і програмах приділяється недостатньо уваги й часу професійній підготовці студентів і їх готовності до педагогічної діяльності. У чинних державних стандартах окреслено обов'язковий мінімум змісту вищої педагогічної освіти, який складається із загальнокультурного, психологопедагогічного та предметного взаємозв'язаних блоків. Загальнокультурний зміст покликано забезпечувати формування та розвиток світогляду викладача, поглиблювати його загальну освіту. Психолого-педагогічний зміст спрямовано на професійну освіту викладача, формування та розвиток педагогічних вмінь, розвиток творчої індивідуальності. Предметний зміст орієнтовано на засвоєння змісту конкретного наукового знання як складової частини загальнолюдської культури, як засобу розвитку особистості студентів та спілкування з ними. Тим самим зазначені аспекти змісту вищої педагогічної освіти підкреслюють той факт, що результативність діяльності вищого навчального закладу визначається особистістю педагога, який має володіти широкими знаннями як у галузі культури, так і в галузі психології, педагогіки та методики навчання тому чи іншому предмету.

Тому перебудова сучасної вишівської системи освіти може бути здійсненою на основі концепції професійно орієнтованої підготовки викладача. На думку 
О. Бабічева, зміст і процес цієї підготовки мають відповідати таким принципам:

- професійно-діяльнісному - визначається системою знань і вмінь, необхідних для навчально-виховних завдань;

- педагогізації - відповідати змісту навчання (при перевазі глибини вивчення матеріалу у вищому навчальному закладі тією мірою, якою це необхідно задля оптимального навчання студентів);

- особистісному - подавати систему формування цілісної особистості викладача як педагогічного мислителя й гуманіста, що володіє педагогічною технікою й технологією, сприяти його індивідуально-творчому розвитку;

- поєднання теоретичної і практичної підготовки;

- послідовної реалізації дидактичної теорії й методичних курсів;

- поширення передового новаторського досвіду - акумулювати у психологопедагогічних дисциплінах, у методиках викладання досвід та ідеї викладачівпрактиків;

- стимулювання дослідницької діяльності студентів у напрямку професійної педагогічної підготовки (особливо у процесі практики), психолого-педагогічної, методичної підготовки студентів;

- активності й самовиховання - спиратися на розумінні фахового зростання як саморуху, обумовленого внутрішніми рушійними силами особистості, самостійною роботою по оволодінню знаннями й формуванню фахових якостей;

- безперервності педагогічної освіти - містити в собі довишівську фахову орієнтацію, безпосередню педагогічну підготовку та відбір, післявишівське творче співробітництво з випускниками [2, с. 142].

Отже, що ж містять у собі концепти «культурологічний підхід», та «культура»? За визначенням деяких науковців $[4,5]$, поняття культура містить у собі історично конкретну сукупність знаково-символічних систем, що акумулюють досвід буття у формі способів мислення, пізнання, переживання і дії, а також у вигляді знань, цінностей, способів, що зберігають і відтворюють досвід власне духовної діяльності в суспільному i особистому менталітеті. Культура - це засіб, що надає людській активності внутрішню цілісність і особливу спрямованість, що виступає як засіб регуляції, відтворення і розвитку усього суспільного життя [5, с. 22]. Культура - це техніка і технологія всіх форм духовно-практичної діяльності людини у світі, форм комунікацій, взаємодії і спілкування [1]. У цьому і полягає нерозривний зв'язок культури і освіти, культури і виховання.

Уперше поняття культурології було згадано в межах антропології при вивченні культури народів. Виходячи за межи антропології, культурологія, з одного боку, стає окремою наукою, з іншого, - важливим складником більшості гуманітарних наук.

У педагогіці культурологія детермінувала явище культурологічної парадигми на всіх іiі рівнях: безпосередньо на рівні парадигми, як загальнонаукового зразка або підходу; на рівні педагогічної методології, технології i, нарешті, на рівні окремих технік і засобів. Культурологічна парадигма орієнтує навчально-виховний процес не на знання, а на засвоєння елементів культури, навчання, поведінки, спілкування, таким способом протиставляючи себе застарілій центричній системі.

Згідно з культурологічним підходом людина містить у собі частину культури, i не тільки розвивається на основі культурних цінностей, але й вносить до неї щось нове, тобто людина стає творцем нових елементів культури. У зв'язку з цим засвоєння культури як системи цінностей, є, по-перше, розвитком самої людини i, по-друге, становленням його як творчої особистості [8]. Культурологічна парадигма породжує 
особливі моделі постановки і рішення педагогічних проблем.

Аналіз сучасних тенденцій і проблем розвитку вищої освіти показав, що і вітчизняна, і закордонна вища школа приділяє особливу увагу вихованню: високі вимоги висуваються не тільки до професійних якостей спеціалісту практично любого профілю, але й до його духовно-морального стану, стосункам 3 колегами, знань національної культури, за допомогою якої людина засвоює цінності свого народу, розвиває свою національну свідомість, здійснює культурну самоідентифікацію, що є домінантою в культурологічній освіті майбутнього фахівця. Проте лише діалог світових культур уможливлює глибину розуміння особливостей національної культури [7].

Згідно 3 навчальним планам та програмам вищих навчальних закладів педагогічного напрямку, теми, що вивчаються, націлені саме на поглиблення культурологічних знань. Обгрунтовуючи такий вибір, необхідно також охарактеризувати цю зумовленість особливостями історичної ситуації.

У другій половині $\mathrm{XX}$ століття - століття індустріалізації та інформаційних технологій - в наше життя увійшло поняття «мультикультуралізм» (від англ. multiculturalism). Хоча 3 впевненістю можна стверджувати, що явище полі культурності сягає ще XV-XVI ст., часів Христофора Колумба та епохи Великих географічних відкриттів.

Сучасне суспільство вже давно живе в умовах глобалізації, коли різні культури так переплелися, що виживання людини забезпечується збереженням рівноваги культурної багатоманітності [6, с. 11]. Сучасна людина реально живе, мислить і діє в просторі багатьох культур, обмежувати вплив яких неможливо і недоцільно. Тому сучасний компетентний фахівець має бути готовим здійснювати професійну діяльність у полікультурному світі, навіть якщо виховувався в певному культурному середовищі та свідомо поділяє його традиції та цінності. Саме цим і пояснюється той факт, що культурологічна освіта студента повинна бути полікультурною, що сприяє розкриттю множинності культурних барв та відтінків.

Українська культура набуває повноти і неповторності лише в співіснуванні 3 різними традиціями світового культуротворення. Саме буття України на стику культур зумовило іiі зв'язок із загальносвітовим історико-культурним простором. Лише в контексті світових процесів українська культура розкриває своє покликання i гуманістичне значення. Тому, на наш погляд, культурологічний підхід у процесі психолого-педагогічної підготовці майбутнього викладача має бути реалізовано саме через гуманітаризацію їі змісту.

Дослідження змісту професійної орієнтації майбутнього викладача на підставі культурологічного підходу вимагає від системи освіти ВНЗ розроблення й упровадження спецкурсів, практикумів семінарів із проблем загальнокультурної підготовки, що забезпечує у свою чергу, свідомий вибір майбутнім викладачем духовних цінностей, формує на їх основі систему професійно-ціннісних орієнтацій (орієнтацій на творчість у професійній діяльності, на розвиток особистості майбутнього фахівця, професійне самовдосконалення та співробітництво, обмін духовними цінностями тощо).

Також необхідно зазначити, що важливу роль у підготовці професійно орієнтованої особистості майбутнього викладача відіграє і педагогічна практика. Під час таких практик навчальна, громадська діяльність студентів знаходить своє втілення безпосередньо в умовах майбутньої професійної діяльності. Саме на практиці вони мають можливість розв'язувати реальні професійні завдання, поповнювати свої професійні знання, навички, вміння. Водночас практика допомагає студентам визначити позитивні і негативні сторони майбутньої професії, глибше усвідомити 
значущість розвитку своїх професійних та особистісних якостей.

У процесі підготовки до педагогічної практики на випускному курсі перед студентом постає низка педагогічних завдань, адже майбутній викладач повинен бути готовим не лише до процесу навчання, а й до процесу виховання, до організації дозвільної діяльності, де особливе значення надається інституту кураторства, до якого студент має бути підготовленим ще під час навчання у вищому навчальному закладі.

Завданням системи виховання в Україні $є$ виховання громадянина. Тому у вищому навчальному закладі суттєвим $\epsilon$ використання теоретичної парадигми національного виховання, запропонованої В. Гнатюком [3, с. 20], через тріаду рис особистості «громадянин - патріот - гуманіст». Вищі навчальні заклади мають здійснювати підготовку інтелектуального генофонду нації, виховання духовної еліти, примножувати культурний потенціал, який забезпечить високу ефективність діяльності майбутніх спеціалістів. Безперечно, велика увага має приділятися використанню виховного потенціалу навчальних предметів, які формують філософсько-світоглядну позицію, науковий досвід, пізнавальну активність і культуру розумової праці, навички самоврядування, соціальної активності і соціальної відповідальності; розвивають почуття любові до Батьківщини і свого народу.

Перспективою подальших досліджень щодо формування професійно орієнтованої особистості майбутнього викладача вбачаємо у вивченні позааудиторної виховної роботи, а саме роботи керівників академічних груп.

\section{Література}

1. Анциферова Л. И. Психологическая опосредованность социальных воздействий на личность, ее развитее и формирование / Л.И. Анциферова // Психологические исследования социального развития личности / отв. ред. И. А. Джидарьян. - М. : Высшая школа, 1991. - С. 5-38. 2. Бабічев О. І. Питання педагогічної підготовки викладача в педуніверситеті / О.І. Бабічев// Ціннісні пріоритети освіти у XXI ст. : матеріали Міжнародної наук.-практ., конф., Луганськ, 11-13 листопада 2003 р. - Частина 4.Луганськ : Альма-матер, 2003. - С. 142-146. 3. Гнатюк В. Зміст і форми національного виховання учнів / В. Гнатюк // Рідна школа. - 1999. - №9. - С. 20-24. 4. Давидович В. Е.

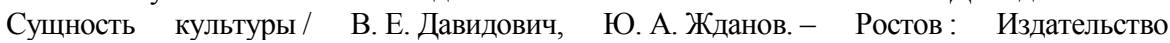
Ростовского университета, 1979. - 264 с. 5. Крылова Н. Б. Культурология образования / Н. Б. Крылова. - М. : Народное образование, 2000. - 272 с. б. Крылова Н. Б. Очерки понимающей педагогики : книга для молодого педагога, ищущего альтернативные пути в педагогике / Н. Б. Крылова, Е. А. Александрова. - М. : Народное образование, 2003. 448 с. 7. Поторій Я. І. Особливості ціннісно-мотиваційної сфери студентів / Я. І. Поторій // Практична психологія та соціальна робота. - 2002. - № 2. - С. 36-39. 8. Протасова Н. И. Динамика профессионального самопонимания студентов-педагогов/ Н. И. Протасова, Б. В. Кайгородов // Мир психологии. - 2001. - № 3 (27). - С. 259-270. 